\section{Péntek Eszter}

\section{Civilek az egészségesebb életért} $\mathrm{Az}$ egészségügyi civil szervezetek szerepe a helyi egészségpolitika alakításában

\section{A gyógyítás társadalmasítása felé}

A hetvenes-nyolcvanas évektől vizsgálatok sokasága számolt be a magyar egészségi állapotról; riasztó mutatókkal és tendenciákkal szemléltetve a nyugati országok társadalmához viszonyított testi és lelki, végsỏ soron az élettartamban és a megélt élet minőségében mutatkozó hátrányokat. A kutatások nemcsak a társadalmak közötti, hanem a társadalmon belüli egyenlőtlenségekről is többé-kevésbé pontos képet adtak. A kilencvenes évek eleje óta pedig számos - nagy vitákat kiváltó - kísérlet látott napvilágot az egészségügyi rendszer átalakítására. Jóllehet az egészségpolitika talán legtöbbet idézett kijelentése szerint ,a lakosság egészségi állapotának alakulásában az egészségügy mindössze 11 százalékban felelős" (Füzesi-Péntek-Tistyán, 2004). Az egészségben maradáshoz az egészségügynek valóban viszonylag kevés köze van (noha a már megbetegedettek gyógyításában nagyon is jelentős). De szintén nem sokat tehet az egészségügyi ellátás területi egyenlőtlenségeinek mérséklésében, a hátrányos csoportok (a különböző betegségekben szenvedők, idősek, szociális hátrányokkal küszködők, fogyatékosok, szenvedélybetegek stb.) megsegítésében sem az amúgy is forráshiánnyal küzdő, tradicionális szemlélettel működő szektor.

$\mathrm{Az}$ előbbi problémák orvoslásában a gyógyítás plurális modellje tűnik működőképesnek. A betegellátási rendszerek társadalmanként különböznek aszerint, hogy mely csoport érdekei jutnak leginkább képviselethez és valóságos döntési hatalomhoz: az állam, az önkormányzat, a helyi közösség és a beteg, az orvostársadalom, vagy a biztosítási rendszerek érdeke a domináns? Az egészségügyi rendszer felépítése erősen hierarchikus, számos ellentétes érdek és érték keveredik benne. Az új egészségügyi kísérletek már több országban próbálják megújítani a megmerevedett struktúrákat és gyógymódokat (Losonczi, 1989, Orosz, 2001). A különböző érdekcsoportok kapcsolatuk során sokféle viszonyt alakíthatnak ki, szembekerülhetnek egymással, szövetkezhetnek is. A kérdés, hogy hogyan jön létre az érdekek képviselete és kifejeződési lehetősége?

A bürokratikus és a nyugati egészségügyi rendszerek közti különbségek megragadására, az egészségügy társadalmi és politikai környezetének vizsgálatára törekvő hazai és nemzetközi elemzésekben egyaránt megfigyelhetỏ az a tendencia, hogy a korábbi ingyenes-nem ingyenes dichotómia helyett egy differenciáltabb, többféle racionalitást és érdekszintet figyelembe vevő elemzésre törekszenek. Ezen magyarázatok közül az életminőség alakulása, az egyenlötlenségek csökkentése terén fontos szerepet játszó helyi egészségpolitika lehetőségeinek feltárása szempontjából kiemelkedő jelentőségủek ॥ különböző integrációs intézmények szerepét, illetve az egészségügy szereplőinek egymáshoz való viszonyát hangsúlyozó megközelítések (Császi, 1989, Antal Z., 1995). A lakossági igények artikulálásában és érvényesítésében a különböző társadalmi integrációs intézmények, mint a család, a szomszédsági kapcsolatok, a civil szervezetek és a helyi közösségek tölthetnek be fontos szerepet. Szükségszerủ továbbá a „gyógyítás” tágabb értelmü használata. Ezen tevékenység eredeti, szubsztantív jelentéstartalma szerint nem szủkül le a testi bajok kezelésére, hanem magába foglalja az egészség megőrzését, a megromlott egészség és szociális állapot helyreállítását, a betegek gondozását és ápolását egyaránt. A szubsztantív tartalmat másfajta racionalitások is hátráltatják. A vallási, ideológiai, politikai, hatalmi racionalitások érvényesülésében érdekelt társadalmi csoportok megpróbálják saját előnyükre kihasználni a gyógyításban rejlő különlegességet - amelynek következtében a szubsztantív racionalitás egyre kevésbé tud érvényesülni. $\mathrm{Az}$ integrációs intézmények szerepét középpontba állító kutatások alapvető törekvése eszerint annak vizsgálata, hogy a társadalom hogyan próbálja a gyógyítástól idegen racionalitások hatását csökkenteni. (Antal Z., 1995).

\section{Nemzeti és helyi egészségpolitikák}

A nemzeti és helyi egészségpolitika meghatározására és elhatárolására csupán kísérletjellegủen vállalkozhatunk, a válaszok ugyanis sok szempontból változhatnak, attól függően, kinek a nézőpontjából, s érdekei/értékrendszere felől közelítünk a problémához. A nemzetközi szóhasználatban (health policy, local health policy) nagyon nagy változékonyságot tapasztalhatunk, a helyi és nemzeti egészségpolitika elkülönítésére nincs egységesen elfogadott meghatározás. Már a „policy” szó használatában sem egységes a kép. A többszintủ politika definiálásában, térnyerésében egyrészt társadalmi tradíciók, másrészt politikai, ideológiai motivációk játszanak szerepet. Nem kapunk egyértelmű választ az említett politikák működésének vizsgálatánál sem: van-e egyáltalán akár országos, akár helyi egészségpolitika, ha a tényleges gyakorlatot vizsgáljuk? Egészségpolitika-e az, ha csak jól hangzó tervek, koncepciók születnek tényleges politikai szándék és akarat nélkül? Az egészségügyi decentralizációt értelmezhetjük úgy, hogy a kormányzat elsősorban az egészségpolitika alapelveinek, az egészségügyi rendszer alakítása fő irányainak és a döntéshozatali kereteknek, mechanizmusoknak a meghatározására törekszik, ugyanakkor a finanszírozás és szolgáltatás területén hozandó konkrét döntéseket a közép vagy helyi szintre ruházza át (Orosz, 2001:236). Kérdés azonban, van-e nemzeti egészségpolitika, amire a helyi egészségpolitika támaszkodhat, segíti annak kifejlesztését, esetleg kikényszeríti annak létrehozását, működtetését? Mi határozza meg, hogy mit tartalmaz egy nemzeti egészségpolitika? Talán közelebb kerülhetünk az egészségpolitikai szintek értékeléséhez, ha a kettő melletti érveket és ellenérveket helyezzük vizsgálatunk középpontjába. A nemzeti egészségpolitika mellett szól egyrészt az, hogy súlyt adhat a helyi egészségpolitikáknak is, illetve erősítheti azokat. Másrészt a nagypolitika szférájában 
is meg kell, hogy jelenjen: alakítja a törvényhozást, a jogszabályalkotást, s a végrehajtás folyamatába is így épül be könnyebben. Gyakran azonban csak deklarációk fogalmazódnak meg - amiket aztán nem követnek intézkedések - melyek természetükől adódóan az általánosságok szintjén mozognak, nem veszik figyelembe a társadalom szegregáltságát. Nem egyértelmű az sem, kinek a feladata a nemzeti egészségpolitika tervezése: az egészségügyi kormányzaté, a kormányé, a parlamenté, avagy a feladat az alulról jövő kezdeményezések összegzése egy nemzeti stratégiában. A helyi politikák „alulról felfelé” modellje ellen is több érv szokott elhangozni. Ezek közül legnyomósabb, hogy a döntések nagy részét a megvalósítás során pillanatnyi kényszerekre reagálva, a körülmények részleges ismeretében, intuitív alapon kell meghozni - a helyi közpolitika tehát bizonytalanságokkal és váratlan fordulatokkal telitetté válhat (Gulyás-Jenei, 1998). A lokális egészségpolitika a népesség egészségi állapotának javításában viszont fontos szerepet tölthet be. Legnagyobb előnye talán az, hogy az adott népesség egészségi szükségleteire tud reagálni. Nagyobb így az esély a megoldásra is, az érintettek fontosabbnak érzik, erőforrást találnak rá, rövidebb távon és hatékonyabban éreztetheti hatását a népesség egészségi állapotában. A közpolitika irodalmában a nemzeti egészségpolitika „felülről-lefelé” modellje esetében a megvalósitás egyéb nehézségeire is rámutattak. Ugyanis amilyen mértékben bonyolultabbá váltak a megvalósitás szervezeti feltételei a magánvállalkozások és a nonprofit szervezetek nagymérvű bekapcsolódásának következtében, olymértékben növekedett az eredményes megvalósítás kockázata a bonyolult kapcsolatrendszerủ hálózatok kiépülése miatt (Gulyás-Jenei, 1998). Nem utolsósorban, a helyi célok megvalósításához könnyebb partnereket találni az adott közösségben; a helyi politika támogatása is nagyobb, és jobbak a feltételek a döntéshozók elszámoltathatóságához.

A helyi egészségpolitikák megvalósulását több tényező is nehezíti. Az ország ma még nagyon centralizáltnak tekinthető, gondolkodásban, erőforrás-elosztásban, stb. A helyi egészségpolitikáknak ennek ellenére ma már hazánkban is találkozhatunk néhány, a gyakorlatban is megvalósult innovatív példájával. Ilyenek: Pécs Város Egészségterve (Füzesi-Tistyán, 1995), az országos Települési Egészségterv Program a Soros Alapítvány támogatásával (Füzesi-Tistyán-Péntek-Szöke, 2001), a Somody Imre nevéhez kötődő Misszió Egészség Program (Albert-Dávid, 2001). Kísérleti programokról lévén szó, a megvalósitáson dolgozó szakemberek és a programok számára különösen fontos célcsoportok (a helyi önkormányzatok, a civil társadalom, az orvostársadalom résztvevő tagjai) is a tanulás fázisában tartanak még, és arra keresik a választ, hogy hogyan készül egy helyi egészségpolitika ideális esetben, és hogyan készülhet az egészségpolitika a gyakorlatban?

\section{A helyi egészségpolitika szereplői}

A rendszerváltásig a kelet-közép-európai országokban a szocialista ,jóléti állam” a különböző szolgáltatások területén nem engedett teret sem a civil szervezeteknek, sem a piacnak. Fel sem merülhetett olyan gyakorlat, mely a nyugati országokra, főleg

az Egyesült Államok nonprofit struktúrájára jellemzö. A rendszerváltást követően viszont új megoldások váltak lehetségessé és szükségessé. A 80-as években született egészségpolitikai elképzelések szerint az állam szerepét részben át kellett volna vennie a magánszektornak, részben pedig a különbözỏ típusú önkormányzatoknak, melyek az egyéneket hivatottak képviselni. Az egyes kormányzati ciklusok egészségpolitikáinak elemzéseiből (Losonczi, 1998, Orosz, 2001) azonban kitủnik, hogy az előbbi elképzelés az első időszakban még szerepet kaphatott, majd fokozatosan átvette helyét az erős központi kormányzat-piac kettős modellje, ahol nincsenek vagy nagyon gyengék a közbülső szervezetek (érdekképviseletek, települési önkormányzatok, civil szervezetek).

Az 1980-as évek végétől alapvető változás következett be általában a civil szervezetek megítélésében. 1987-től ismét lehetővé vált az alapítványtétel, két év múlva pedig elfogadták az egyesülési szabadságról szóló törvényt ${ }^{1}$, megteremtve a társadalmi önszerveződés törvényi garanciáját. A civil szerveződések nyolcvanas években megindult lassú növekedése a politikai rendszerváltozást követően rendkívül felgyorsult (Kuti, 1998). Egymás után alakultak az egészségügyi intézmények és a betegek támogatására, valamint képviseletére megszerveződő alapítványok és egyesületek. A civil szervezetek olyan partikuláris érdekeket fejezhettek ki, és olyan kérdésekre is választ kerestek, amelyek kiesnek a társadalmi gondolkodás és az állami feladatvállalás körébỏl (Lévai, 1998).

A nonprofit szervezetek szolgáltatásokba történő bevonását a nonprofit kutatók (Bocz 2001, Szalai 1997, Kuti 1998, Széman-Harsányi 1999) több tényezỏvel magyarázzák. Egyes elemzések a kis költségekre, a nagyobb rugalmasságra, a marginális csoportok jobb elérhetőségére, a kisebb bürokráciára hivatkoznak. Mások a szolgáltatók és az ellátottak közötti kisebb távolságot hangsúlyozzák, és sokan említik a nonprofit szervezetek innovatív szerepét a speciális problémákkal küzdỏ társadalmi csoportok (pl. szenvedélybetegek, fogyatékosok, krónikus betegek stb.) megsegítésében, a hátrányos helyzetủ csoportok érdekeinek képviseletében és a társadalmi szolidaritás erősítésében. Hasonlóan fontos érv azonban a nonprofit szervezetek bevételszerző képessége, illetve az, hogy az állam ritkán képes eleget tenni az összes társadalmi szinten felmerült igénynek, melyek sok esetben a piacra és a nonprofit szektorra hárulnak.

Az egészségügyi alapítványok és társas nonprofit szervezetek hazai helyzetéről jórészt a KSH adatfelvételei adnak aktuális képet $(K S H, 2001)$. Rendkívül részletes adatokat nyerhetünk a szervezetek tevékenységét, gazdasági-és humán tőkéjét illetỏen is (bevételi források, pénzügyi kapcsolatok, alapítók, foglalkoztatottak és segítők), nem adnak azonban témánk szempontjából kellően differenciált képet az egészségügyi nonprofit szervezetek mủködésének körülményeiről, kapcsolatrendszeréről, arculatáról, politikai kultúrájáról, vagyis a döntéshozatalban, az egészségpolitika alakításában való részvételi szándékok meglétéről vagy hiányáról. Területi szempontból az utóbbi összefüggések felkutatására első lépésben - többféle megfontolásból - a regionális szint, az egy-egy régión belül működő civil szervezetek köre valamint a regionális hatókör és kapcsolatrendszer kiemelt vizsgálata látszott indokoltnak. Nem 
mellö́zve azt az elôzetes hipotézist, mely szerint a helyi egészségpolitika lehetséges színterévé válhat a régió. A régió hazai értelmezése és helyzete az elmúlt 15 éves gyakorlat és régiópolitikai vita nyomán azonban némi kiegészítésre szorul. Az Európa Unióhoz való csatlakozás deklarálásával Magyarországon is szükségessé vált a helyi és területi szintek szereplőinek partnerségi elvű együttmủködése, és az ezt lehetővé tevő intézményrendszer kiépítése. Az elemzésekből azonban ismert, hogy a települési hatáskörök megerősítését nem követte, a demokratikus decentralizált rendszer megteremtéséhez szükséges szintek közötti hatalommegosztás kialakítása.

A rendszerváltás a települési önkormányzatiság megteremtését követően nem terjedt ki a területi szintre. A megyék intézményfenntartó és szolgáltató feladatköréből adódóan a megyei területfejlesztési tanácsokból hiányzik a direkt politikai irányítás, lévén a KSH által felülről létrehozott területi egységek, amelyek ugyanilyen adminisztratív módon kialakított kistérségi statisztikai egységekből épülnek fel (Soós, 1999). Az európai integrációs folyamatban a decentralizáció a régiók irányába fejlődött, s ma már egyre több tagállamban politikai funkciók ellátására is alkalmas területi egységnek tekintik a regionális szintet. A regionális fejlődés elősegítése és a regionális ügyek iránti elkötelezettség azon felismerés eredménye, hogy a helyi önkormányzati egységek méretük, pénzügyi korlátaik és alkotmányos jogaik következtében alkalmatlanok az európai és nemzeti politika formálására és végrehajtására, $s$ inkább elősegítỏi és koordinátorai a köz- és magánszektorral folytatott munkának.

Maga az állam is átalakult, többé már nem képes a térbeli tervezés irányítására, hatalma és hatásköre felülről a nemzetköziesedés, alulról a helyi és területi követelések, oldalról a piac és a civil társadalom nyomására csökkent. A régió viszont fontos közvetítő funkcióval bír mind funkcionális, mind területi értelemben. Közbülső szerepéből adódóan alkalmas terület a központi és a helyi önkormányzati érdek, közérdek találkozására, ezáltal a mobilizáció fontos szintjét jelentheti. Magyarországon 1994-ben azonban az önkormányzati törvény tárgyalása során a megye továbbra is megmaradt középszinten, mint koordinatív keret. A régió, mint lehetséges alternatíva nem fogalmazódott meg a rövidtávú elképzelésekben. A regionális funkciók mủködtetésében - akarva, akaratlanul - az önkormányzatok váltak főszereplőkké. Történt ez egyrészt az önkormányzatiság lényegébő́l fakadóan, az önkormányzati törvény és a különböző hatáskörök jogi szabályozásából adódóan, az országos döntéshozatal szándékainak megfelelően, másrészt a feladatokat felvállalni tudó más gazdasági, illetve társadalmi szervezetek hiányában (Gadócziné, 1993). A döntések kimenetelére jelentős hatással bírhat viszont a helyi önkormányzatok környezete: a település gazdasági és társadalmi csoportjai, a társadalom tagjai. A helyi közösség mint környezet és az önkormányzat közötti kommunikációban jelentős szerepet tölthetnek be a különféle érdekcsoportok, melyek a pártokkal súly helyezódik az els területek érdekeit próbálják megjeleníteni. Itt nagy hangsúly helyeződik az elsajátított kommunikációs módszerre és a tevékenység során kifejeződỏ politikai kultúrára. A döntések kimenetelét jó esetben meghatározza az egymásrautaltság, mely jelenti a helyi önkormányzatok közötti együttműködést, és a civil és más szervezetekkel való kapcsolatrendszer kialakítását is. A szolgáltatások

22 nagy részének az önkormányzati szféra hatásköréből való kikerülésével a kapcsolatrendszerek komplex hálózata alakul ki.

A lokális egészségpolitikák kialakítása eredetileg a helyi/területi önkormányzatok feladata közé tartozik, amennyiben tetten érhetők a részvételre vonatkozó cselekvési lehetőségek és hajlandóságok.

A hazai vizsgálatok ehhez képest az önkormányzatok egészségpolitikai szerepének csökkenéséről számolnak be (Orosz, 2001), miszerint az önkormányzat és a többi szereplő közti kapcsolat esetleges, csupán információk cseréjére szűkül (Füzesi-Tistyán, 1995), és alapvető problémát jelent a térségi infrastruktúrafejlesztéshez elengedhetetlen együttműködés hiánya. Az önkormányzatok körében folytatott vizsgálatok alapján elmondható az is, a hogy az önkormányzat ellenőrző szerepe is folyamatosan csökken (Antal Z., 1995). Az ellátás megítélésére hivatottak egyre inkább a gyógyítást végzőktől szerzik be az információkat. Adódik ez abból, hogy az orvostudomány és a technikai feltételek - laikusok számára követhetetlen - fejlődéséből adódóan, a döntéshozók képtelenek a gyógyító eljárások hatékonyságának megítélésére, aminek következtében nemcsak az orvosok-betegek, hanem az orvosok és a gyógyító tevékenységet ellenőrzők között is nagyfokú információs asszimmetria alakul ki.

Jóllehet az önkormányzati hatáskör csökkenni látszik, az egészségpolitikai elemzések rámutattak arra is: annak ellenére, hogy a decentralizáció nem állt az egészségügy irányításának átalakítására kidolgozott koncepciók középpontjában az elmúlt 15 év során, számos folyamat decentralizációként értelmezhető. Mégpedig kétféle értelemben, mikro- és mezoszinten: a központi kormányzat és az egészségügyi intézmények, valamint a központi kormányzat és a mezoszint szervezeti egysége közti kapcsolatot tekintve (Orosz, 2001). Eszerint az egészségügy müködésében is meghatározó egységgé válnak a helyi szint és az országos szint közötti mezoegységek. Az egészségügyi ellátás hazai sajátosságait elemző írásokból úgy tűnik, hogy a régió „olyan funkciókat valósíthat meg, amelyeknek eddig nem volt gazdája. A térségi stratégiai tervezést, a fejlesztések, a struktúra átalakításának koordinációját és ezek érdekében a régió egészségügyének folyamatos elemzését, a lehetséges alternatíva kidolgozását” (Orosz, 2001: 239) (lásd: regionális biztosítók koncepciója, regionális egészségügyi tanácsok létrehozása stb.). Vagyis a régió méreténél fogva kiemelt színtérül szolgálhat a helyi egészségpolitikák kidolgozásához.

\section{A Dél-dunántúl egészségügyi nonprofit szervezeteinek vizsgálata}

A következőkben bemutatott kérdőíves vizsgálat annak a kutatási folyamatnak a része, mely a helyi egészségpolitika potenciális szereplőinek az egészségmegőrzésről, gyógyításról, az egészségpolitika tartalmáról, irányairól, az abban való társadalmi igények és érdekek megjelenítéséről való véleményét, szándékait, s az azok mögött meglévő vagy hiányzó lehetőségeket szeretné megismerni. (A 2003-ban, a Dél-dunántúli régió három megyéjében végzett kérdőíves vizsgálat a PTE Bölcsészettudományi Kar Dékáni Hivatalának támogatásával készült.) A vizsgálat kiemelten kezeli a helyi

2005 - ősz 
szereplök - az önkormányzatok, az egészségügyi civil szervezetek, az egészségügyi dolgozók szakmai érdekképviseleteinek - kapcsolatrendszerének feltérképezését, mely a helyi egészségpolitikák elkészítésének és müködtetésének legfőbb potenciálja lehet. Az első vizsgálat a Dél-dunántúli régió három megyéjében (Baranya, Somogy, Tolna) működő közel 500 egészségügyi tevékenységet ellátó nonprofit szervezet körében készült. A korábbi kutatásokkal (Szalai, 1997, Papházi, 1997, Bocz, 2001) ellentétben itt azért a bírósági nyilvántartás szolgált alapul, mert a KSH forrásokban nem szereplő, már nem, vagy aktívan nem működő szervezetekről kapott információk is fontos részét képezték az elemzésnek. A vizsgálat adatai 2003-ra vonatkoznak, az eredmények a százalékos megoszlásokat tekintve azonban többségében ma is helytállóak, hiszen a vizsgált szektor jelenleg is hasonló strukturális (gazdasági, jogi) körülmények között működik, ami a vizsgált mutatók kiegyensúlyozottságát valószínűsíti.

A kérdőíves vizsgálat teljes körủ megkérdezésre törekedett. A nyilvántartásban szereplő majd 500 szervezet fele működött a vizsgálat időpontjában aktívan, körükben a válaszadási hajlandóság a levélben történt megkeresést követően $40 \%$-os volt, aminek eredményeként e szervezetek vezetőitől, képviselőitől 104 értékelhető kérdőív érkezett vissza. (A nem mủködő szervezetek közül is válaszoltak 39-en, ezekből működésük megszünésének körülményeiről nyerhettünk képet). Az alacsony elemszám természetesen módszertani korlátokat jelent, a kérdőívek elemzése során statisztikailag szignifikáns összefüggések helyett többnyire jelzésértékủ - a véletlenszerüséget kiküszöbölni nem tudó - eredményeket kaphatunk, ezek azonban a további kutatási irányok kijelölése céljából rendkívül hasznos információként szolgálhatnak.

A megyék közti megoszlás a kérdőívet visszaküldő aktív szervezetek körében viszonylag egyenletes. A székhelyüket illetően viszont - a nonprofit szektorra általánosságban is jellemző - városba koncentrálódás figyelhető meg: a szervezetek fele megyeszékhelyen, további egynegyede egyéb városban mủködik, és csak egynegyedük található községben. A városba koncentrálódás egyik oka a szoros intézményi kötelék: az egészségügyi intézményrendszer is a nagyvárosokba összpontosul, így az ezekhez kötődő szervezetek területi elhelyezkedése is ehhez igazodik. A szervezetek kiterjedtségében működési területüket tekintve a helyi/települési és regionális szint dominál. Többségük (60\%) alapítványi formában, $15 \%$ közalapítványként müködött az adatfelvétel idôpontjában, az egyesületek aránya 25\%-ot tett ki. Ez az országos átlaghoz képest az egyesületek nagyobb súlyát mutatja az egészségügyi szektorban. A KSH követéses vizsgálataiból tudjuk, hogy az egészségügyi nonprofit szervezetek hamar felismerték a közhasznú besoroláshoz kapcsolódó előnyöket, s gyorsan reagálva e lehetőségre az 1990-es évek végére nagy részük meg is tette az ehhez szükséges adminisztratív és jogi lépéseket (Bocz, 2001). Ennek megfelelỏen a vizsgálatban szerepló szervezetek háromnegyede rendelkezett ezzel a státusszal (65\% volt közhasznú, $9 \%$ kiemelten közhasznú).

A vizsgálatban résztvevő nonprofit szervezetek tevékenységi körük szempontjából nagyjából az országos átlagnak felelnek meg. Vagyis nagy arányban (30\%) a kórházi és intézeti ellátás támogatására létrehozott szervezetekkel találkozhatunk. Emellett azonban az országos felmérésekben regisztráltnál kissé nagyobb arányban
(11\%) fordulnak elő a három megyében olyan alapítványok és egyesületek, amelvek kifejezetten közegészségügyi célokat vállalnak fel, illetve a szervezetek $56 \%$-a dolgozik egy-egy társadalmi csoport (bizonyos betegségekben szenvedők, hátrányos helyzetủek, idősek, fogyatékosok, szenvedélybetegek, fiatalok stb.) megsegítéséért. Izek egy része föleg anyagi segítséget vállal (konkrét pénzbeli segítség mellett vásárlások, szolgáltatások megszervezését is), egy része programok szervezésével, a közösségi élet megteremtésével járul hozzá e csoportok életminőségének jobbításához. De tevékenységi körükben fontos helyet kap saját segítőik érdekvédelme és szakmai segitése is.

A kérdőívben előre megadott válaszkategóriák - ötfokú skálán való - értékelését követően megállapítható, hogy a vizsgálatban szereplő szervezetek elsősorban ↔ hazai lakosság rossz egészségi állapotának javításában való közreműködést tartják Iz egészségügyi nonprofit szervezetek fő rendeltetésének (ez a szempont az ötfokú skálán átlagosan 4,06-os értékelést kapott). Másodsorban feladatuk csak az egészségügy krónikus zavarainak enyhítése, valamint a modernizációs, fejlesztési törekvések támogatása (átlagosan 3,85-ös értékelés). Ebben, úgy tűnik, teljes az összhang, a szervezetek különböző jellemzői mentén nincs számottevő különbség. Egy másik, részletesebb itemsort tartalmazó kérdésre kapott válaszok sorrendisége megfelel a fenti kérdésre adott válaszoknak: első helyen prevenciós, egészségmegőrző feladatokat vallanak magukénak az alapítványok és egyesületek, másodsorban komoly feladatokat szánnak maguknak az egyenlőtlenségek mérséklésében. De hetedik helyen szerepel (3,93-as átlagértékkel) a témánk szempontjából fontos civil érdekképviselet is az egészségpolitika formálásában. Az egészségügy anomáliáinak orvoslását a szervezetek közepes mértékben tartották fontos feladatuknak, a sorrendben hátrább foglalnak helyet ezek a szempontok.

A nonprofit kutatások visszatérő megállapítása (egy-egy nagyobb szervezetet leszámítva) a szervezetek körében tapasztalt általános anyagi szükösség. Vagyis a civilek nagy része a lelkes indulást követően nagyon nehezen talál anyagi forrásra, támogatókra (a kezdeti támogatók lelkesedése, ha volt ilyen, idővel lanyhult). Megfelelő infrastrukturális háttér (iroda, írószerek, számítógép, egyéb technikai berendezések) hiányában a forrásszerző munka még inkább megnehezül (gondoljunk csak a rendkívül bonyolult, hosszadalmas, komoly előkészítést igénylő európai uniós támogatásokra stb.). Az ehhez szükséges humán kapacitás is sokhelyütt hiányzik: alkalmazottak híján az alapítók, segítők munkájuk mellett, szabadidejükben végzik civil tevékenységüket, kezdetben erejüket meghaladó mértékben, majd általában kedvüket vesztve. Vagyis az alapítványok, egyesületek nagy része léte fennmaradásáért, mindennapos anyagi gondokkal küzd. Ezt mutatta a felszerelésre, ingatlanra és a munkát segítő berendezésekre ${ }^{2}$ vonatkozó adatfelvétel is. A nagy hangsúlyt kapott kapcsolati tőke és forrásszerzés szempontjából fontosnak tartottuk a média és az információ szerepét, önálló weboldallal azonban a szervezetek közül mindössze 5, folyóirattal/hírlevéllel/rovattal 10, internetes hozzáféréssel a válaszadók egyharmada (28) rendelkezett. A szervezetek közül 60 nem érhető el telefonon, 31 nem rendelkezik bútorzattal, berendezkedéssel és 23-nak nincs önálló irodája/helyisége sem, ahol ügyeit intézhetné. A községekben működő szerveze-

$2005-$ ősz 
tek nagy részének rendelkezésére áll önálló iroda, helyiség, bútorzat, ami vélhetően a helyi önkormányzattal való együttmüködés eredménye. A bevételi struktúrát tekintve a régió egészségügyi nonprofit szervezetei az országos képet mutatták. A vizsgált évben rendelkezésre álló adatok alapján az előző évben - és a korábbi időszakban is-, a szervezetek bevételei nagyon nagy szórást mutattak: egy év alatt 17 ezer forinttól 60 millió forintig terjedő összegből gazdálkodtak.

A nonprofit szervezetek kétharmadát magánszemélyek hozták létre. Ez megfelel annak a kívánatos trendnek, hogy a szervezetek alapvetően állampolgári kezdeményezésként jöjjenek létre. Egyötödüket alapították önkormányzatok illetve piaci szereplők. Néhány esetben regisztráltunk csak olyan szervezetet, ahol az alapító egyház vagy egyéb alapítvány, egyesület volt. Foglalkozásukat tekintve az alapító tagok között ugyanolyan arányban (35-35\%) találhatók az egészségügyi és a nem egészségügyi szakemberek. Az előbbiek alapján látszik, hogy a szervezetek jó néhány esetben már indulásuk pillanatában kapcsolódtak más szektorhoz, a vegyes jóléti modellnek megfelelően. A nonprofit szektor általános vizsgálataiból tudjuk, hogy az állami, önkormányzati szervek, intézmények gyakran alapítanak nonprofit szervezeteket. Az ilyen típusú félig kormányzati, félig civil szervezeteket a nemzetközi szakirodalom „quango"-nak (quasi nongovernmental organisation) nevezi (Kuti, 1998). A szoros intézményi kapcsolatok hátterében föként a szűkösség áll alapvető strukturális tényezóként, vagyis a nonprofit szervezetek állami, önkormányzati feladatok biztosításában, az egészségügy financiális eredetű gondjainak mérséklésében, a pénzügyi kiszolgáltatottság csökkentésében játszanak fontos szerepet. Másrészt az egészségügyi intézmények és az önkormányzatok bekapcsolódása a nonprofit szférába, a szervezetek többségénél erősödő kapcsolati hálóra utal.

A szektor erősségét, stabilitását a nonprofit szervezetek közötti kapcsolati intenzitás jellemezné leginkább. A nonprofit kutatásokból ismert megállapítás, hogy bár a civil szervezetek sokszor tủnnek egymással és más szereplőkkel ellenérdekelt versenytársaknak, a tapasztalatok sokasága azt látszik bizonyítani, hogy e szervezetek sűrű hálózata végül is mégiscsak olyan struktúrát alkot, mely sikeres lehet az együttműködés során a közérdek képviseletében (Lévai, 1998). Emellett, ha az érdekviszonyokban az együttműködés dominál, akkor a közpolitikai döntéshozatal nem formális, hanem valódi kompromisszumok keretében valósul meg. Ezt azonban a vizsgálatból nyert eredmények alapján az egészségügyi nonprofit szervezetek körében csupán gyenge közepesre értékelhetjük. A válaszokból ugyanis megállapítható, hogy az érintkezések eseti jellegủek és föként lokálisak: a szervezetek közül mindössze 3 került müködése során rendszeres, és 9 eseti kapcsolatba külföldi nonprofit szervezettel. Országos szinten is inkább az alkalmankénti kapcsolatfelvétel jellemző. A legtöbb érintkezés a nonprofit szervezetek között helyi szinten történik: a vizsgált szervezetek egyharmada tart fenn alkalmankénti, egyötöde rendszeres kapcsolatot helyi szerveződésekkel. A helyi szektorális kapcsolatok mellett - több dimenzió mentén - vizsgáltuk az egészségügyi civil szervezetek egészségügyi, szociális intézményekkel, helyi önkormányzattal, más nonprofit szervezetekkel, egyházzal, szaktárcával/főhatósággal, vállalatokkal/ vállalkozásokkal és külföldi szervezetekkel való kapcsolatát is.
1. sz. ábra: Az egészségügyi szervezetek együttmüködési intenzitása más szereplökkel

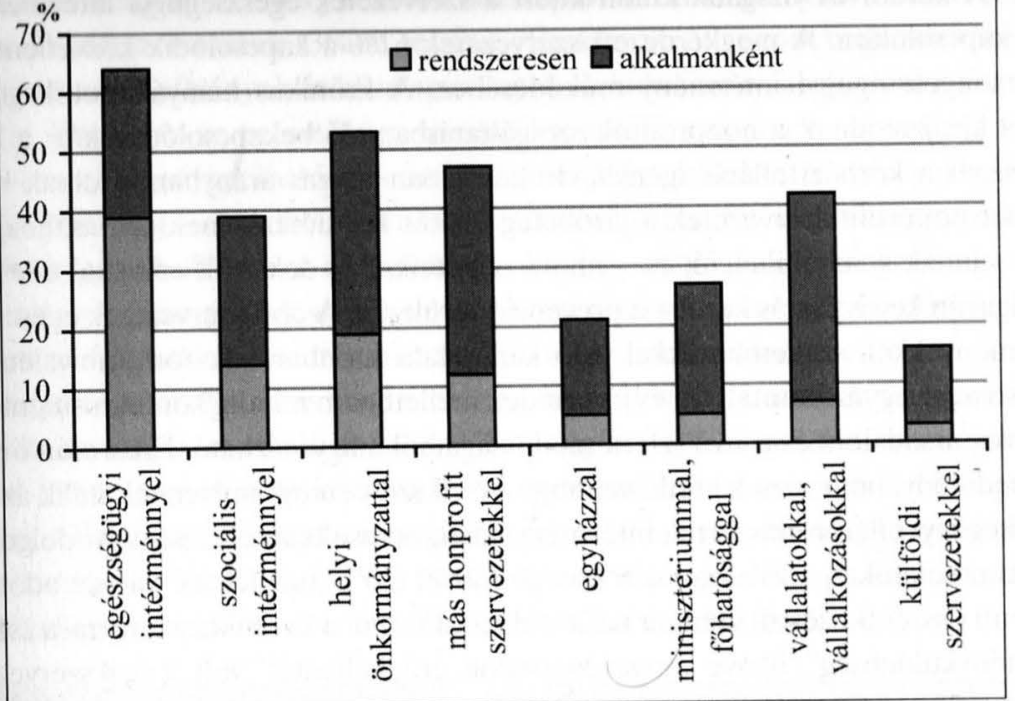

A kapcsolatok kiépítéséhez természetesen idő kell, nem meglepő tehát, hogy a felsorolt szervezetekkel, intézményekkel a már több mint 3 éve működő nonprofit szervezeteknek van igazán működő (rendszeres vagy alkalmankénti) kapcsolatuk. Ez a különbség a saját nonprofit szférán belüli kapcsolatokra még inkább érvényes, ahol a kapcsolatrendszer erőssége és kiterjedtsége leginkább a 10 vagy több éve fennál 16 szervezetek esetében a legszembetűnőbb. A szervezeti forma szerint az alapítványok gyakrabban keresik fel a szakminisztériumot és a piaci szereplőket (vállalatokat, vállalkozásokat), mint az egyesületek - a többi szervezettel, intézménnyel való viszonyukban ilyen különbségek nem tapasztalhatók. A település típusa szerint szembetűnő eltérések a szervezetek között a helyi önkormányzattal való kapcsolat intenzitásában mutatkoztak: míg a községben müködő egészségügyi civil szervezetek $50 \%$-a rendszeres, $37 \%$-a alkalmankénti kapcsolatot tart fent a helyi vezetéssel, addig ez az arány a városi szervetek esetében csak 28 és 35\%. Korábbi vizsgálatokból azonban tudjuk, hogy ez az összefüggés nem véletlen, hiszen a községekben jellemzőek a személyi összefonódások: sok esetben a település háziorvosa az egészségügyi civil szervezet vezetője és az önkormányzat képviselőtestületének tagja is egyben (FüzesiPéntek-Tistyán, 2004). Nyilvánvalóan a civil szféra városba koncentrálódása miatt a városi szervezetek körében sokkal több olyan van, aki rendszeres kapcsolatba kerül más nonprofit szervezettel, de például az egyházhoz való kötődések a községekben működő civilekre jellemzőek nagyobb mértékben. Az alapító tagok foglalkozását tekintve az egészségügyi intézményekkel rendszeres kapcsolatot tartók aránya kétszer akkora az egészségügyi foglalkozású, mint a nem egészségügyi foglalkozású alapítókkal rendelkező civil szervezetek körében - ez, több más tényező mellett, az egészségügy szektoriális összefonódásait jelképezi. A szaktárcával való kapcsolat rendszeres- 
ségét illetổen szintén kimutatható ez a különbség az alapitók foglalkozása mentén, de az nem olyan nagy mértékü, mint az elöbbi esetben.

A kérdőíves vizsgálat külön kitért a szervezetek egészségügyi intézményekkel való kapcsolatára. A megkérdezett szervezetek $62 \%$-a kapcsolódik közvetlenül valamilyen egészségügyi intézmény mủködéséhez. A krónikus hiányállapotok gócpontjai jól kirajzolódnak a nonprofitok szolgáltatásba való bekapcsolódásakor: a legtöbb segítséget a kórházi ellátás igényli, de hasonlóan magas arányban járulnak hozzá a vizsgált nonprofit szervezetek a járóbeteg ellátás körülményeinek javitásához, illetve jelen vannak a rehabilitáció, és - ahova a politikailag deklarált célokkal ellentétben már igazán kevés forrás kerül - a prevenció területén. A civil szervezetek egészségügyi intézményekkel, szakemberekkel való kapcsolata azonban sokszor ambivalens: ez a kapcsolat az egymásrautaltság és jó szándék mellett nem mindig konfliktusmentes, ami az orvostársadalom és a civil szféra sajátosságaiból magyarázható. Ezek után örvendetes eredmény, hogy arra a kérdésre, hogy a civil szervezetek milyennek ítélik az állami egészségügyi ellátórendszerrel, intézményekkel, orvosokkal, egészségügyi dolgozókkal való kapcsolatukat, a válaszadók többsége (58\%) ,jó”, ,megfelelő” választ adott. Esetenkénti összeütközésről számolt be 20 válaszadó, ahol a konfliktusok forrása „szakmai véleménykülönbség”, illetve „presztízsgondok, érdekellentét” volt. 9 civil szervezet vallotta az egészségüggyel való kapcsolatát kifejezetten „rossznak”, ennek okát mindegyik esetben „érdekellentétként” jelölték meg. (A válaszadók nyitott kérdésben, szabadon jellemezhették a konfliktus kiváltó motívumait, e válaszok csoportosításából született az előző két kategória, ám természetesen ezek között szoros összefüggés valószínűsíthető: a szakmai nézetkülönbségek eredhetnek az egészségügyben dolgozók és a civilek közötti érdekellentétekből, az érdekellentétek pedig gyakran szakmai vitákban artikulálódnak.) Az egészségügyi intézményekkel, dolgozókkal gyakori konfliktusokról beszámoló civil szervezetek jellemzően régebbi (3 vagy több éve működő) szervezetek. A kifejezetten rossz viszonyt említő civilek községben találhatók, az esetenkénti összeütközéseket pedig a városi civilek jelölték. Az alapító tagok szerinti bontásban az orvostársadalom differenciálódására, a gondolkodásmódok változatosságára utalhat az, hogy az egészségüggyel konfliktusos viszonyt említő civil szervezetek közül négy olyan is van, melyek tagjai maguk is egészségügyi foglalkozásúak.

Amennyiben a helyi egészségpolitikát többszereplős helyi stratégiának fogjuk fel, miszerint a közpolitika egy olyan komplex jelenség, amely döntések sorozataiból áll, amelyet számtalan egyén és szervezet közreműködése hív életre (Gulyás-Jenei, 1998) és azt vizsgáljuk, hogy annak kialakításában, artikulálásában milyen szerepet játszanak a szervezetek, ennek egyik mutatója lehet az önkormányzat döntéshozatali munkájában való részvétel szintje. Korábbi kutatások (Füzesi-Tistyán, 1995) eredményeit támasztja alá a vizsgálatban tapasztalt rendkívül alacsony aktivitási szint, miszerint a vizsgált szervezetek körében mindössze 9 vesz részt az önkormányzattal közös munkában állandó partnerként, 11 ad hoc bizottságban, 18 felkért szakértőként és csupán 9 szervezet tagja egészségügyi, szociális kerekasztalnak. Az aktivitási szintet az önkormányzattal való közös munkában az befolyásolta, hogy mióta működik a szervezet. A 3 évnél régebben alakult szervezetek döntéshozásban való (politikai es szakértői) részvétele nagyságrendekkel nagyobb, mint az 1-2 éve alakult társaiké. A válaszokból úgy tủnik, hogy szervezeti forma alapján aktívabbak az egyesületek, mint az alapítványok: 25\%-os jelenlétükhöz képest az önkormányzat állandó partnereként müködő szervezetek $43 \%$-át teszik ki. Szakértőként viszont nagyobb arányban szerepelnek az alapítványok és közalapítványok az önkormányzatok munkájában. Az egészségi állapot és az egészségügy területi egyenlőtlenségeinek mérséklése szempontjából nem elhanyagolható az a területi különbség, miszerint a községekben - jelenlétükhöz képest - nagyobb aktivitás mutatkozik. A pozitív jelek ellenére azonban a korábban tapasztalt szoros összefonódások (nagyszámú önkormányzati alapítók) és az alacsony együttműködési hajlandóság közti diszkrepancia még kérdéses marad, annak pontos okainak felkutatásához további vizsgálatok szükségesek.

A szervezeteket arról is megkérdeztük, hogy idővel nehezedtek vagy javultak-e munkakörülményeik az elmúlt években? Többségük (69\%) úgy vélte, munkájuk nem változott számottevően megalakulásuk óta, egyharmaduknak jelentős nehézségekkel kellett szembenéznie, és csupán a megkérdezettek 4\%-a mondta azt, hogy munkájuk könnyebb lett. A vizsgálatba bevont nonprofit szervezetek munkáját megnehezítő és megkönnyítő, leggyakrabban említett tényezők a következők voltak.

\begin{tabular}{|l|c|}
\hline Munkát megnehezítő tényezők & említés \\
\hline anyagi forrás hiánya & 53 \\
\hline $\begin{array}{l}\text { időhiány, önkéntes segítő munka } \\
\text { hiánya, nehézsége }\end{array}$ & 41 \\
\hline $\begin{array}{l}\text { közömbösség a társadalom } \\
\text { részéről }\end{array}$ & 28 \\
\hline $\begin{array}{l}\text { elutasítás az egészségügyi dolgo- } \\
\text { zók részérool, a szemléletváltás } \\
\text { lassúsága }\end{array}$ & 14 \\
\hline $\begin{array}{l}\text { túlzott adminisztráció, bürok- } \\
\text { rácia }\end{array}$ & 31 \\
\hline $\begin{array}{l}\text { anyagi források esetlegessége } \\
\text { (mindenkori sikeres pályázatok, } \\
\text { támogatások függvénye) }\end{array}$ & 12 \\
\hline
\end{tabular}

\begin{tabular}{|l|c|}
\hline Munkát megkönnyítő tényezők & említés \\
\hline önkormányzati anyagi segítség & 35 \\
\hline $\begin{array}{l}\text { folyamatosan épülő kapcsolatok } \\
\text { helyi, regionális és országos szinten }\end{array}$ & 19 \\
\hline $\begin{array}{l}\text { média támogatása, ismeretség - ez- } \\
\text { által az elfogadottság növekedése }\end{array}$ & 18 \\
\hline $\begin{array}{l}\text { regionális, országos módszertani } \\
\text { központ, Civil Kerekasztal, civil } \\
\text { referens segítsége }\end{array}$ & 8 \\
\hline $\begin{array}{l}\text { egyéb nonprofit szervezetek segít- } \\
\text { sége }\end{array}$ & 17 \\
\hline $\begin{array}{l}\text { nyitottság növekedése az egészség- } \\
\text { ügy felöl (kórházi helyiség rendel- } \\
\text { kezésre bocsátása, orvosok nyitott } \\
\text { gondolkodásmódja stb.) }\end{array}$ & 17 \\
\hline
\end{tabular}

A vizsgálat egyik központi kérdése volt az, hogyan látják az egészségügyi nonprofit szervezetek saját szerepüket, lehetőségeiket a helyi egészségpolitika alakításában, egyáltalán hogyan gondolkodnak a helyi egészségpolitika tartalmáról, jelentőségéről Természetesen a korábban már jellemzett kérdés összetettsége, a róla való ismeretek fogyatékossága miatt megválaszolásakor számolnunk kell a kérdőíves módszer standard kérdéseinek korlátaival. Ebből kiindulva az egészségpolitikára vonatkozó részek leginkább nem számszerűsíthető, nyitott kérdésekből álltak, módszertani szempontból pedig a vizsgálat ezen szelete inkább további kutatások kiindulópontjaként szolgál, semmint a tényleges álláspontok és gondolkodásmódok pontos megismerésére. A kérdőívet kitöltő szervezetek tehát szabadon fejthették ki véleményüket arról, hogyan jellemeznék a nemzeti és a helyi egészségpolitika szerepét, illetve azt, hogy kinek a feladata a nemzeti és a helyi egészségpolitika tervezése, formálása? 
Nem utolsósorban arra kerestük a választ, hogy milyen feladatot vállal(hat)nak ebben a civil szervezetek? A nagyarányú válaszmegtagadás mutatja a téma és a fogalmak újszerüségét. A nemzeti és helyi egészségpolitika feladata, szerepe tekintetében a konkrétabb válaszok a helyi politika estében születtek (szintén nyitott kérdésként szerepelt a kérdôívben, a válaszok pedig a következỏ kategóriák közé csoportosultak).

\begin{tabular}{|c|c|}
\hline A nemzeti egészségpolitika feladata, szerepe & A helyi egészségpolitika feladata, szerepe \\
\hline országos fejlesztési programok kidolgozása & $\begin{array}{l}\text { ugyanaz, mint a nemzeti egészségpolitikának, } \\
\text { települési megvalósításban }\end{array}$ \\
\hline $\begin{array}{l}\text { rendelkezésre álló pénzeszközök racionális el- } \\
\text { osztása }\end{array}$ & $\begin{array}{l}\text { ugyanaz, mint a nemzeti egészzégpolitikának, } \\
\text { regionális megvalósításban }\end{array}$ \\
\hline $\begin{array}{l}\text { prevenció, egészségnevelés országos szintủ } \\
\text { múködtetése }\end{array}$ & a nemzeti célok megvalósulását elősegíteni \\
\hline $\begin{array}{l}\text { a lakosság egészségi állapotának javítása, célja } \\
\text { az egészséges nemzet }\end{array}$ & $\begin{array}{l}\text { ugyanaz, mint a nemzetinek, a helyi jellegü } \\
\text { problémák (betegségcsoportok, társadalmi hát- } \\
\text { rányok) kiemelt kezelésével }\end{array}$ \\
\hline $\begin{array}{l}\text { helyi szintü programok kidolgozáśhozoz, végre- } \\
\text { hajtásához szükséges anyagi támogatás biztosí- } \\
\text { tása }\end{array}$ & $\begin{array}{l}\text { helyi problémák feltérképezése, azokra cselek- } \\
\text { vési programok kidolgozása, a helyi szereplök } \\
\text { összefogásával }\end{array}$ \\
\hline $\begin{array}{l}\text { az életkörülmények és a szociális helyzet javittá- } \\
\text { sa, mivel ezek szorosan összefüggnek az egész- } \\
\text { ségi állapottal }\end{array}$ & $\begin{array}{l}\text { a helyi egészségszervezetek összefogása, } \\
\text { munkacsoportok felállítása, közös munka az ön- } \\
\text { kormányzattal }\end{array}$ \\
\hline $\begin{array}{l}\text { a kormány által létrehozott nemzeti stratégiák } \\
\text { megvalósitása }\end{array}$ & prevenció helyi megszervezése \\
\hline $\begin{array}{l}\text { a társadalmi, demográfiai változások következ- } \\
\text { ményeire való gyors reagálás }\end{array}$ & ettségek teljesítése, \\
\hline törvényi elöírások betartása & $\begin{array}{l}\text { helyi közösség önsegítỏ képességének növelése } \\
\text { (pl. háziorvosok, civilek segítségével), egészség- } \\
\text { kultúra helyi szintư javitása }\end{array}$ \\
\hline $\begin{array}{l}\text { megelőzó, gyógyyitó, helyreállító egészzégügy } \\
\text { megszervezése, és összehangolása a lakossági } \\
\text { igények felmérése alapján }\end{array}$ & $\begin{array}{l}\text { munkahelyek biztositása, a lakosság számára } \\
\text { többszintú, jó színvonalú, mindenki számára } \\
\text { elérhetô szolgáltatás múködtetése }\end{array}$ \\
\hline $\begin{array}{l}\text { az egészségügyi dolgozók megbecsülésének } \\
\text { elősegítése }\end{array}$ & $\begin{array}{l}\text { források racionális, helyi igényekhez alkalmaz- } \\
\text { kodó elosztása }\end{array}$ \\
\hline
\end{tabular}

A válaszok összesítése alapján elmondható, hogy a nemzeti egészségpolitika elkészítése a szervezetek szerint a mindenkori kormány, szakminisztérium (vagyis a „nagypolitika”) feladata a szakma közreműködésével. Figyelemreméltó azonban, hogy 13 szervezet válaszaiban megtalálható a civil részvétel igénye is a döntéshozásban, stratégiai programok kidolgozásában. Helyi szinten első helyen szintén a vezetés és a szakma (orvosok és szakmai érdekvédelem) részvétele áll, de már a nemzetinél fontosabbnak tartották a szervezetek azt, hogy egyéb szereplők is bekapcsolódjanak a közérdek védelme mellett a - fóként önkormányzati - munkába.

Arra a kérdésre, hogy milyen feladatot vállal(hat)nak ebben a civilek, a vizsgált szervezetek nagy része negatív tapasztalatokról számolt be. Vagyis arról, hogy a helyi stratégiák és döntések meghozatalakor a döntéshozók nem tartanak igényt a véleményükre, nem kérik meg előzetesen javaslataikat. Jóllehet - állítják a szervezetek fontos, mindennapi munkájukból nyert tapasztalatokból származó információkkal egészíthetnék ki ezt a munkát, nagyobb teret igényelnének a programok kidolgozásában és azok operatív végrehajtásában, megszervezésében is. A megkérdezett szervezetek válaszaikban kiemelték az összekötő szerepüket is a város/település vezetése és a lakosság között, mely magába foglal egyfajta információs, mozgósító tevékenységet, de egyben ellenőrző funkcióval is bír a lakosság felöl.

Összességében elmondható, hogy a nonprofit szervezetek (helyi és nemzeti) egészségpolitikáról alkotott képe meglehetősen szerteágazó: a skála az elképzelések teljes hiányától a pontosan megfogalmazott „ideáltipikus” képig terjed. A vizsgálatbôl az is kitűnik, hogy a válaszokban kifejezésre juttatott szándék ellenére ma még a đöntéshozatalban való civil részvétel nagyon alacsony. Egy biztosan állítható: a nemreti szintű válaszok mellett szükség van a helyi szintű válaszok kidolgozására is. A következő évtizedekben - az ismert egészségi mutatók mellett - drámai demográfiai változások is érintik az országot, benne szinte minden régiót. Új feladatok, új gondok az önkormányzatok, a családok, az egyének, a szociális és egészségügyi ellátó szféra számára. Az államnak ehhez a feltételeket kell megteremtenie, az egyéneknek, közösségeknek pedig felelősséget kell vállalni az egészségesebb döntésekben.

\section{Jegyzetek}

Az 1989. évi II. tv. az egyesülési jogról.

A kérdőívben felsorolt eszközök, ingatlanok, a munkát segitő berendezések a következők voltak: önálló iroda, számítógép, Internet hozzáférés, önálló weboldal, folyóirat/hírlevél/rovat, telefon, fax, földtulajdon/ingatlan, bútor/berendezés, fénymásoló, gépjármü, technikai/gyógyászati eszközök, naturáliák/gyógyszerek.

\section{Felhasznált irodalom}

Albert F.-Dávid B. (2001): Lehetséges-e innováció az egészségügyben? In: Susánszky Éva-Szántó Zuzsa (szerk.) Egészség-Közösség-Misszió. MTA Szociológiai Kutatointézet, Budapest. Antal Z. L. (1995): A gyógyitás társadalmi beágyazottsága. Szociológia. 1.sz. 3-23. Bocz J. (2001): Egészségügyi nonprofit szervezek Magyarországon. KSH, Budapest. Császi L. (1989): Az egészség egyenlótlenségeinek interpretációja Magyarországon. Társadalomkutatás 2. sz. 42-58. Füzesi Zs.- Tistyán L. (1995): Pécs Város Egészségterve. Fact Alapítvány, Pécs.

Füzesi Zs.-Péntek E.-Tistyán L-Szöke K. (2001): Települési egészségtervek. A Falu. 3.sz. 71-64. Füzesi Zs.-Péntek E.-Tistyán L. (2004): Az egészségügyi ellátás területi egyenlötlenségei. PTE, Pécs. Gulyás Gy.-Jenei Gy. (1998): Bevezetés a közpolitikába. BKE, Budapest.

Kuti É. (1998): Hívjuk talán nonprofitnak... Nonprofit Kutatócsoport, Budapest.

Kuti É. (szerk.) (1992): A nonprofit szektor Magyarországon. Tanulmányok. Nonprofit Kutatócsoport, Budapest. Kuti É.-Marschall M. (szerk.) (1991): A harmadik szektor. Nonprofit Kutatócsoport, Budapest.

Lévai K. (szerk.) (1998): Civil a pályán. Helyi Társadalom Kutatócsoport, Budapest.

Losonczi Á. (1989): Ártó-védó társadalom. Ahogy a társadalom betegít és gyógyít. Közgazdasági és Jogi Könyvkiadó, Budapest.

Losonczi Á. (1998): Utak és korlátok az egészségügyben. MTA, Budapest.

Orosz É. (2001): Félúton vagy tévúton? Egészségügyünk félmúltja és az egészségpolitika alternativái. Egészséges

Magyarországért Egyesület, Budapest.
Soós E. (1999): Integráció és regionalizmus. Bába és Társai K. Szeged.

Szalai J. (1997): Az egészségügyi alapítványokról. INFO-Társadalomtudomány. 42. sz.

Széman Zs.-Harsányi L. (1999): Halak és hálók. Kapcsolatok a helyi szociálpolitikában. Nonprofit Kutatócsoport, Budapest. 